\title{
Immersed In Time
}

Sean Cubitt

\section{Contemplation}

In his 2003 work Spread, American artist James Turrell presents a hole in a wall with steps leading up, so that you can gaze into the space beyond, which is filled with blue light, a light whose source is not apparent, and which saturates the space beyond, shapes and confounds it, so that you are unsure of whether the space is deep or shallow, but intensely aware of the light. In an interview with PBS, Turrell notes that he wants to make "work that is light, as opposed to being about light" (Egg 2007). In a move that is clearly of the age after Einstein, the physicality of light, its proximity to matter or thingliness, and its dimensionality, are present in the room. The physics of space-time are here formally and experientially divorced from any informational content, at least in any sociological terms ('being about light'), the work effectively a kind of perceptual game freed from the psychology lab and set free in the gallery. Not unlike, in this respect, Anish Kapoor's poured pigment installations, whose dimensions are lost in the sheer ravishment of colour, Turrell's work is incommunicative, yet fascinating, and of course beautiful. It fascinates like fire, and as Turrell observes,

we tend to stare into the fire in a not-thinking state, not thinking in words. And this kind of glazed-eye looking into light is not any different than the deer that looks into the headlights before it's hit by the car. I want to use that quality -- work that is light, as opposed to being about light. (Egg 2007)

Such immersion Turrell believes to be primal, an effect of the externality of the eye, its emergence into the world, its receptivity, the first pleasure of illumination, even before the appreciation of movement.

Such experiences of immersion are temporal, though much of the literature on immersive media suggests analogies with virtual space. The time of immersion is a curiosity because 
it so rarely matches chronometric time. A familiar experience from the history of private silent reading, and more recently from the apparent mismatch between the time experienced watching a film and the hours that have gone by unnoticed when we emerge from the cinema into the street, immersion in narrative forms has been an available escape from quotidian stress, and the butt of humour, for centuries. It can be usefully contrasted with boredom, the intensified experience of time passing that is perhaps most intensively exemplified by waiting. The kind of immersion offered by Turrell's works is of neither order, neither the condensation of action into narrative streams nor the painful awareness of the body's time that waiting produces. The not-thinking, the glazed-eye look, are perhaps meditative states, and yet they are not entirely static: merely unstressed or uninflected time, more contemplation than meditation. In ecological works like the Roden Crater near Flagstaff, Arizona, or the more modest Skyspace installed in the Scottish village of Kielder Turrell is careful to include the sense of cosmic time as well as space, the simple remoteness of the place itself a marker of its intersection with historical time, and the time of the everyday. It is for this reason I use the word 'beautiful' as opposed to 'sublime', a term which refers to an extra-historical temporality, a temporality without words because it is asocial, in Levinas' terms total rather than infinite and, to that extent, anaesthetic. Meditation confronts being as totality; contemplation makes its approach to infinite becoming, a time-based, time-oriented and time-consuming activity whose beauty arises from the fact that it can be disputed (as indeed is the case with Turrell, who notoriously was once sued when a visitor to a Whitney installation tried to lean on an apparent 'wall' of light and fell over).

The dimensions of physical events occur in both time and space. Turrell's intangible 'wall' is clearly spatial, and in interviews he often speaks of his work in relation to architecture. But the event of the falling spectator is clearly temporal, both as physical event and as a perceptual equivalent of mismatched language-games. The irruption of a law suit into the space of art is a boundary conflict in the social system, and as such brings two organisations of time into conflict, the one contemplative, the other based on biographical scales of time in the witnessing process, and on a teleological temporality in the trial situation's orientation towards the goal of resolution or sentencing. The clash of these temporalities is itself temporal, but in a way that disturbs the organisation of time in both sub-systems, and specifically that disrupts the immersive experience by insisting on 
another and conflicting temporality that cuts across it. The clash with legal time, however, acts like the careful framing of artificial or natural light in Turrell's work, a foil against which the actual time of these artworks appears all the more intensely.

While ordinary usage of the term contemplation permits the use of language, it does not necessitate it. On the other hand, contemplation does imply the passage of time, as Merleau-Ponty adumbrates in a passage describing what happens 'if I contemplate the house attentively and with no thought in my mind' (it is hard not to think here of Rachel Whiteread's absurdly affecting temporary artwork House),

We shall forget our present perception of the house every time we are able to compare our memories with the objects to which they refer, we are surprised, even allowing for other sources of error, at the changes which they owe to their duration. But we still believe that there is a truth about the past; we base our memory on the world's vast Memory, in which the house has its place as it really was on that day, and which guarantees its being at this moment (Merleau-Ponty 1962: 79, 81)

Likewise, he points out, the double horizon of retention and protention, of the past and the future in the present as the future of its past and the past of its future, produce the present's presence as something more than a fleeting event, identifying it is an objective moment. The very stillness of Turrell's work draws towards it a contemplation of this objective kind, in which the objectness of the object displays itself to a gaze which recognises itself as the recipient of that display, bringing to it the memory of other perceptions, and the expectation of a certain future which they bear with them (as the falling visitor demonstrates so well). The ecological, natural-light works which articulate with the changing light of the sky are even more likely to generate a sense of the time of viewing, the experiential time of a contemplation in which the experience is as strongly marked as the objective changes in the light by transition and becoming, a step away from the defining objectness of the object towards awareness of becoming rather than being. Armed with that experience, to return to one of Turrell's artificial light works is to become attuned to your own changing perception, the multiplication of vision in the indefinite forms taken not simply by light and space but by the gaze that partners them in the constant recreation of form out of light's energy, oscillating between modes of recognition, misrecognition and surprise. 


\section{Distraction}

Because it is neither an image nor moving, Turrell's gallery installation tells us a great deal about visual communications which are both. Jennifer Steinkamp's Jimmy Carter of 2002 is a projection on several walls, in which long strands of flowers and tendrils like William Morris wallpaper twist, sway and tangle silently in an invisible wind. Like Turrell, Steinkamp has also worked on the massive scale in her 2000 installation Aria for the Fremont Street Experience in Las Vegas, a ninety feet high and four blocks long projection of abstract forms swirling overhead on the arched ceiling of a mile-long mall. Jimmy Carter is a more modest yet still compelling piece of work. Like the Turrell, and despite its title, it seems to have little to communicate in verbal terms, except possibly a response to the taunt of 'moving wallpaper' occasionally leveled at dull movies, and perhaps a slight pastiche of Warhol's Empire, the $16 \mathrm{~mm}$ film he made of the Empire State Building which he referred to as 'moving wallpaper'. Steinkamp's flowers have the look of watercolour illustrations to botanical field guides, but are clearly digitally produced and reproduced in their massed forms on the gallery walls. By cunningly placing her projectors at angles (and presumably allowing for the 'keystone' effect of projecting at anything other than ninety degrees to the wall), Steinkamp invites the visitor to observe their shadows multiply and dissolve unpredictably, seeming to vanish behind one bundle of flowers while casting a shade still on a neighbouring one, producing a delightfully bewildering uncertainty about the depth of light on the wall. Like many of her works, Jimmy Carter produces perspectival illusions, although in this case the projection without shadows seems to occupy the shallowest of fields. It is only when interrupted by the viewer that the projections seem to reveal their layering. In this sense alone is the work interactive.

As Peter Lunenfeld noted of her earlier work, Steinkamp's projections are 'dependent upon technology, though resistant to anything but direct experience. Fully simulated before being installed, it must be engaged bodily to be appreciated and understood' (Lunenfeld 2000: 156). Though idiosyncratic and, with the exception of her architectural installations, severed from everyday life by their position in galleries, Steinkamp's works are in many respects typical of quotidian media, those light sources, like television sets, we observe and interact with physically everyday. Those of us who grew up with cinema were amused by the TV generation who failed to understand the primary principle of projection, and 
failed to recognise their own shadows as they stood in the beam during lecture screenings. But they and we are alike in our oblivious passing between viewers and domestic screens, a relation that has only increased as individual TVs in separate rooms and personal screens viewed in extreme proximity have taken over from the architectural scale of living rooms and cinemas. The wavering halo of illumination that surrounds someone standing in front of a cathode ray tube is not lost of cinematographers, but is rarely observed in daily life, and yet it forms a singular aura in the lighting of most domestic and many public spaces. Best observed from outdoors looking into houses in the evening, the flicker of the TV and its constant changes of tone and brilliance create lightscapes of surprising variety once stripped of their narrative content. It is this aspect of the banal media that inhabits Steinkamp's works. Their invitation to immersion is the more fascinating for its echo of the everyday, unobserved immersion in the artifice of electronic light.

Meticulous, as almost any new media art must be, these careful works might seem to occupy a time of their own apart from the world, but as Lunenfeld observes, they require the viewer, and the viewer's shadow most of all, their place in the system of light as absorbers and reflectors, to make the work complete or even visible. Where Turrell's works are contemplative or inspire contemplation, Steinkamp's reach out to the body that perceives, coating it in light, inveigling it into activity, presenting it with mechanical rhythms that, like techno music, invite to biological movement. Like music, these works immerse, and like music invite not only to participate but to observe others participating, to dance and watch the dancers, to become social.

Preposterously non-judgemental, Steinkamp's Las Vegas Aria has the shiny colours of pinballs and gaming machines. Socialisation is not utopian for her, or rather its utopian moments are not divorced from the present of capital. Like many artists from the US West Coast, her art is not critical but celebratory. Like Gene Youngblood, whose Expanded Cinema might have been written for her, Steinkamp makes work that at once revels in the technical capabilities of each medium she employs, and at the same time encourages her art to surge out of the confines of the frame and enjoy itself. Though some works are less than jolly (I overheard a child describing one projection at the San Jose Museum of Art career retrospective as 'a creepy tree'), it is exuberance and colour that remain with you after leaving the show. Rather differently to Turrell, who often builds spaces specifically to 
produce his light effects, Steinkamp is an architectural artist, though one who works as much with interiors as exteriors. The key difference however is in their relation to time.

Steinkamp, like so many electronic, digital or video artists, employs repetition. The order of repetition she employs is rather different to either the US flicker-film artists, notably Paul Sharits, or the structural-materialist filmmakers in Europe, among whose works Kurt Kren's $T V$ (1966) is perhaps the most rigourously structured in repetition. The intention is far less deconstructive, and the repetition far less aggressive. More like the structured use of layered repetitions employed in West Coast musical minimalism by Terry Riley, perhaps most clearly in In C, and in early Steve Reich, the layered repetitions of Steinkamp's Jimmy Carter do not give a sense that time is being edited and recur, like Kren's work, but that certain ordered events, of a kind with musical figures, are being repeated across the projections, and that the projections themselves are continuous in a way that is only technically explicable through looping; but that not all the loops are of the same duration, so that their repetitions do not sync up but provide a layered experience whose whole is rarely if ever entirely repetitive, even as its parts are.

As Peter Gidal notes of Kren's film,

the shot itself "abstracts" from documenting the pro-filmic, the extracinematic, what the camera is aimed at, into rhythmic fragments and montage. But there are never fragments-of, i.e. of a whole. We are confronted with the impossibility of adequately lengthy perceptual identification of the represented. In this film, a process made of durations, the quantity of time, is not sufficient for anything to proceed,

concluding that 'Repetition expels identity' (Gidal 1989: 144-5). Steinkamp's repetitions are quite different. They are indubitably fragments-of, even though their distance from any profilmic reality is extreme, and to that extent even though it may be that the flowers derive from actual botanical instances, they are presented as ideal types processed as digital painting rather than as photographic recordings, i.e. there is no sense in which they pretend to depict actual plants and flowers, and the connection with real plants and flowers is never established or needed, since the reference, to the extent that there is one, is to previous depictions of flowers. With its imbrication of the viewer's body into the fabric of the work, Jimmy Carter scarcely 'expels identity'. But neither does it confirm it. Instead, it suspends identity in a present which, while subtly different from the immediate past, is not 
absolutely distinct from it in the way that Merleau-Ponty's house is different, capable of surprising. Memories of where the flowers were a moment ago are, even if possible, redundant. Their movement is as directionless as ripples on a pond, motion about rather than motion towards. The sense of delight they afford neither premises a spectatorial identity, nor enforces one: unlike the cinema, you can move about the space, into the beam or out of it, or stand still anywhere within it. The joy in movement that pursues so swiftly the pleasures of illumination produces a very different fascination to Turrell's contemplative, wordless thinking, a social alertness in the sense of Merleau-Ponty's apperçu that the see is to enter into the field of the visible, to make yourself visible to the world and to others in the world. Unlike Turrell's work, Steinkamp's addresses this presence of the spectator. Yet the work does not therefore produce an identity, only a bodily and visible presence. Nor does it require language, although both the referentiality and the socialising field of visibility entertain its possibility.

The temporality of these movements is then one of simple succession. The experience of viewing is potentially but not necessarily verbal or speakable. It is in this sense distracting, in the sense of a diverting entertainment, and in the sense that it distracts the everyday viewer from the everyday, calling them to be mindful of the unnoticed banality of illumination by media screens, rather than their content ('moving wallpaper'). Elsewhere in the field of vision there is always another movement, always another twisting braid, to distract from the one we are watching right now. The sense you have is of a bounded infinity, something like Flusser's (2000) thought that the photographic apparatus exists to produce all possible photographs. Just so, you feel, the work of Jimmy Carter will only be done when every molecule of wall has been illuminated with every colour in the palette. The endless impossibility of completion is the grounds on which the work distracts from what is merely given, assumed, known.

\section{Phenomenology of the Loop}

Dryden Goodwin's one thousand nine hundred and ninety six (1996) is a 16mm film loop comprising one thousand, nine hundred and ninety six frames, each taken at the same spot, looking down from a motorway bridge onto a rectangular patch of road just big enough to show a single car. Projected at 24 frames per second, there isn't time to identify each vehicle, only the patch of road they share. Of all the anonymous placeless places, 
Augé's (1995) non-places of supermodernity, the motorway must be the least marked, the most transitory, one where pedestrians are banned so that any kind of embodied experience of the materiality of the place $s$ reserved for emergency professionals, the site otherwise abandoned by the truly embodied from the day it was opened to traffic. Goodwin's installation sanctifies one anonymous rectangle of road in the commonality of all the vehicles that have been and that will be here, in this exact same spot, each for a fleeting fraction of a second, occupying a grid point on the map that will forever link them, all unknown, to one another. Bill Viola (1988) used to talk about a future cult that would worship old CCTV cameras and resurrect their selfless memories of empty parking lots and the drip-feed of people walking across them or starting or parking their cars. Unblinking, unconcerned with form, CCTV is the last bastion of realism. It cares for its patch of ground as a duty owed, and that patch, under that care, becomes itself, as no uncared for patch can ever wholly be. The interchangeability of one map cell for another is denied by this seizure of the repeated but endlessly varied evidence of inhabitance. Goodwin's retro-engineering of CCTV makes possible a new mode of place, anonymous but perpetually linking all who pass through it, a community shared and as unalienable as it is unconscious, indeed because it is unconscious.

Viewing the apparatus installed, which includes the projector and film strip strung out to display its length as well as the projected image, the machinery impresses with its anonymity, a convincing analogon of the anonymity with which the motorway endows its citizens. In return, the viewer's gaze is aligned with that of the CCTV-like apparatus, with the surveillant rather than the surveilled, who remain hidden inside their cars. The loop performs itself, indicating the impossibility of total knowledge: these might be any cars, with any passengers or none, repeated or simply showing endlessly the endless flow of traffic. The experience is curiously disembodying, as though the apparatus, which is transparently based on recording, had captured an eternity, even though the motorway is of course as entirely historically specific as the models of the cars on it. As impersonal as any grid square on any map, the apparatus impersonates the viewer, as if we were vacated by personal memories and have grafted the purposeless cycle of overseeing the overlooked.

The term ubiquitous is overused of media and surveillance. This anodyne patch of 
highway would remain unobserved were it not for the artist's near-random choice. Yet the possibility of ubiquity, the capacity to focus on anything, is as profoundly human as the capacity observed by the poet Miroslaw Holub to search for hours under the sofa for a lost collar stud. As a fantasy, it inhabits early imaginings of television like those in the Hollywood International House (1933) and the British High Treason (1929), both of which picture television having the ability to visualise anything in the world on demand. As disturbance, it troubles news organisations receiving citizens' media footage from disasters and trouble-spots where normal procedures for double-checking provenance and accuracy do not apply and the pressures of $24 / 7$ reporting diminish the time available to check. As loop, one thousand nine hundred and ninety six reports on the banality of truth, the endless supply of truth overwhelming our capacity to care, while offering an exemplary act of caring as a kind of penance, or a suggestion for a different appreciation of the Keatsian equation between truth and beauty, one that does not include human knowledge, or leaves it on the sidelines, a pleasant enough addition but inessential.

It is most of all the inessential nature of it all - the choice of this patch of ground, the camera angle dictated by or dictating that choice, the random number of frames (random in the sense that without the title we would have no idea how many there are), the unforeseeable amount of time any one viewer will opt to spend with the piece - that severs this piece from the humanism of both Turrell and Steinkamp. At both ends of the process in the cars and in the gallery - there are humans, but the links between them, and between all the others who will pass through both non-places, are arbitrary. Once again, the immersion of spectator in time is not communicative, or perhaps more distinctly, is a communication without content. To the extent that it socialises, it is phatic, but those imaged in one thousand nine hundred and ninety six (and many other of Goodwin's works) are ignorant of the fact that they have been caught on camera, even though, as motorway drivers, they must know that at arbitrary points on their journey they will be viewed by speed cameras, having contracted to donate themselves to the field of surveillant visibility in return for speed.

The order of the unsigned contract is the characteristic underpinning of visual communication in the age of accelerated capitalism. As long ago as 1977 Dallas Smythe observed that 'The material reality under monopoly capitalism is that all non sleeping time 
of most of the population is work time', a thesis recently developed by Jonathan Beller to suggest that 'Cinema and its succeeding (if still simultaneous) formations, particularly television, video, computers, and the internet, are deterritorialised factories in which spectators work, that is, in which we perform value-productive labor' (Beller 2006: 1). Perhaps what is most significant about these pre-communicative and a-communicative modes of immersion is that they encourage modes of engagement that are not work; that inspire contemplation, distraction or impersonation, and open the door to many other modes of temporal organisation, all of which potentially escape the focused, valuecreating, unpaid labour of viewing on which the image economy of contemporary capital depends. Through their apolitical, pre-narrative forms, such works indicate not only a negative aesthetic of refusal but modes of attention that benefit no-one except to offer sensual, useless refreshment, and to indicate that there are modes of immersion which are neither selling us goods and services, nor require unsigned contracts to provide significance to news and fictions, by offering time rather than offering to while it away or spend it. The considerations of time occasioned by such immersive works can instead offer new ways to understand the ways in which time is stolen from us in our everyday media, and how through inattention, distraction, contemplation and impersonation, we might be able to steal it back.

\section{REFERENCES}

Augé, Marc (1995), Non-Places: Introduction to an Anthropology of Supermodernity, trans John Howe, Verso, London.

Beller, Jonathan (2006), The Cinematic Mode of Production: Attention Economy and the

Society of the Spectacle, Dartmouth College Press / University Press of New England, Lebanon NH.

Egg (2007), "Interview with James Turrell",

http://www.pbs.org/wnet/egg/215/turrell/interview_content_1.html, accessed

1.1.2007.

Flusser, Vilém (2000), Towards a Philosophy of Photography, trans Anthony Matthews, intro Hubertus Von Amelunxen, Reaktion Books, London.

Gidal, Peter (1989), Materialist Film, Routledge, London.

Levinas, Emmanuel (1969), Totality and Infinity: An Essay on Exteriority, tr Alphonso Lingis, Duquesne University Press, Pittsburgh. 
Lunenfeld, Peter (2000), Snap to Grid: A User's Guide to Digital Arts, Media and Culture, MIT Press, Cambridge MA.

Merleau-Ponty, Maurice (1962), Phenomenology of Perception, trans Colin Smith, Routledge, London; Routledge Classics edn 2002.

Smythe, Dallas (1994), 'Communications: Blindspot of Western Marxism [1977]' in

Smythe, , Counterclockwise: Perspectives on Communication, ed Thomas Guback, Westview Press, Boulder CO., 266-291; orignial Canadian Journal of Political and Social Theory, v.1 n.3, Fall 1977, pp 1-27.

Steinkamp, Jennifer (2006), reel, quicktime movie, http://jsteinkamp.com/quicktime/html/reel.html

Viola, Bill (1988) 'Y aura-t-il copropriété dans l'espace des données?' in Communications 48.

Youngblood, Gene (1970), Expanded Cinema, Studio Vista, London. 


\section{University Library}

\section{- M I N E R VA}

\section{A gateway to Melbourne's research publications}

Minerva Access is the Institutional Repository of The University of Melbourne

Author/s:

Fredrickson, A;Snyder, PJ;Cromer, J;Thomas, E;Lewis, M;Maruff, P

Title:

The use of effect sizes to characterize the nature of cognitive change in psychopharmacological studies: an example with scopolamine

Date:

2008-07-01

\section{Citation:}

Fredrickson, A., Snyder, P. J., Cromer, J., Thomas, E., Lewis, M. \& Maruff, P. (2008). The use of effect sizes to characterize the nature of cognitive change in psychopharmacological studies: an example with scopolamine. HUMAN PSYCHOPHARMACOLOGY-CLINICAL AND EXPERIMENTAL, 23 (5), pp.425-436. https://doi.org/10.1002/hup.942.

Persistent Link:

http://hdl.handle.net/11343/35069 